\title{
The bribery perceptions of Indonesian business sectors: Sand the wheels or grease the wheels?
}

\author{
R. Rokhim, N. Wulandary \& R.E.F. Nasution \\ Universitas Indonesia, Indonesia \\ W. Thohary \\ Transparency International Indonesia, Indonesia \\ W. Jatmiko \\ Durham University, UK
}

\begin{abstract}
This paper aims at testing two main hypotheses debated among corruption researchers: "sand the wheels" and "grease the wheels" in the Indonesian business sectors. The "Sand the wheels" hypothesis argues that corruption has a negative impact, while the "grease the wheels" hypothesis argues that corruption has a positive impact. Using the data from the Bribery Risk Perception According to the Business Sector survey conducted by Transparency International Indonesia and the provincial Gross Regional Domestic Product (GRDP), this study provides a descriptive overview of the business sector bribery perceptions and maps it against the provincial GRDP of 11 sample cities. The result shows that the larger the sector was, the higher the bribery perceptions that the sector had. Sectors dealing with natural resources such as mining, oil and gas, and forestry were perceived to have the highest bribery potential across all the sample cities. In terms of the two corruption impact hypotheses, the bribery cases in Indonesia confirmed the "grease the wheels" hypothesis since they occurred in sectors with higher provincial GRDP.
\end{abstract}

\section{INTRODUCTION}

Corruption is one of the most challenging problems faced by developing countries, including Indonesia. According to the Gallup World Poll (2013), 88\% of the Indonesian people consider corruption practices to be prevalent in the government sector. However, not only the public sector, corruption has plagued the private sector. One of the most widespread corruption practices in the private sector is bribery. Bribery in the private sector will certainly impede overall economic growth. Several studies have proven that corruption could impede a company's growth and ultimately impact their economy in the aggregate. This hypothesis is known as "sand the wheels". On the other hand, further studies discover that corruption has a positive impact. This hypothesis is called "grease the wheels". According to this hypothesis, corruption helps in improving efficiency when a government has a poor bureaucratic system.

Based on the two hypotheses, this paper aims at providing a descriptive overview of the business sector bribery perception and mapping it against the GRDP generated by each sector. To give an overview of the effect of corruption in Indonesia, the Gross Regional Domestic Product (GRDP) of business sectors in the 11 sample cities was used as a variable. When the GRDP of a sector is high and its level of bribery is also high, the "grease the wheels" hypothesis is accepted. On the contrary, when the level of bribery is high, while the GRDP is low, it indicates the "sand the wheels" hypothesis effect. 


\section{LITERATURE REVIEW}

The impacts of corruption practices are often two sides of the same coin. According to the "grease the wheels" hypothesis, corruption improves efficiency in a business process.

Several studies support this hypothesis, such as Leff (1964), Leys (1965), and Huntington (1968). These studies reveal that in a country where bureaucracy is inefficient (highly centralized administration, excessive regulatory burden, and weak bureaucracy system), corruption practices could boost efficiency in business processes by minimizing lead time. Another study by Lui (1985) shows that bribery could remove constraints caused by a lengthy administration process and shortens queuing time in public facilities. Dreher \& Gassebener (2007) show that the many procedures and the minimum amount of required capital negatively impact the launch of a new company into the industry, but through corruption, the negative effect of these regulations can be softened.

Contrary to the "grease the wheels" hypothesis, Mauro (1995) found that corruption negatively impacted investment and ultimately impeded its growth. Kaufmann \& Wei (1998) tested the hypothesis using the company-level data and found the companies that paying bribes spent substantial time negotiating with other countries' representatives. Svensson, in another study, finds that bribery practices typically arise when a company has to deal with the government, especially when dealing with export, import, and infrastructure service acquisition (Svensson 2000). A study by Kimuyu (2007) on manufacturing companies in Kenya proves that a company, on average, pays $14.2 \%$ of its total contract value to government officers. On the other hand, Pham \& Takayama (2015) investigated the relationship between corruption and a company's efficiency in Vietnam and found that a company that practices bribery from early on usually has to pay higher amounts of bribes over time.

\section{METHODOLOGY}

This study employed primary data from the 2015 Corruption Perception Index conducted by Transparency International Indonesia. More specifically, it employed Bribery Risk Perception According to Business Sector Survey. The respondents of this survey were

1,067 manufacturers from 11 cities: Manado, Bandung, Banjarmasin, North Jakarta, Makassar, Medan, Padang, Pekanbaru, Pontianak, Semarang, and Surabaya. They were provided with questions about their perception of bribery risk in other sectors, using a Likert scale questionnaire. Scale 0 shows that bribery practice is "Very Common", while the scale 5 "Very Uncommon". The questions were divided into four subcategories: (i) Potential for Bribery to Win a Business Competition, (ii) Potential for Bribery to Expedite an Administrative Process, (iii) Potential for Bribery in the form of a Political Donation, and (iv) Potential for Bribery in Other Private Sectors. The answers to the four-category questions were calculated to get the average bribery perception score of each business sector in 11 sample cities. Then, the average bribery perception score of each business sector in each city was mapped against the city's GRDP by province.

\section{RESULTS AND DISCUSSIONS}

\subsection{Bribery risk according to business sector}

The results show that the potential for bribery practices is perceived to be very high in the construction and mining sectors, both having an average bribery score of 3.41, followed by the oil and gas sector. According to Stansbury's data (2005), at least four reasons are contributing to the fact that the construction sector is prone to corruption: uniqueness, the complexity of transaction chains, the high level of official bureaucracy, and the large scale of investment. Since every project is unique, construction companies have the freedom to set higher costs, and this will go undetected as none of the projects is similar enough for comparison. 


\subsection{Percentage of bribery to production cost}

Based on the perception of the percentage of bribery to production cost, the construction sector had the highest portion of bribes. According to the data from the Global Infrastructure Anti-Corruption Centre, companies in the construction sector have spent sizeable money on their production costs because massive investments are involved. In this case, bribes can easily go undetected. Following the construction sector was the service sector in the second place that covers many subsectors, such as education and health.
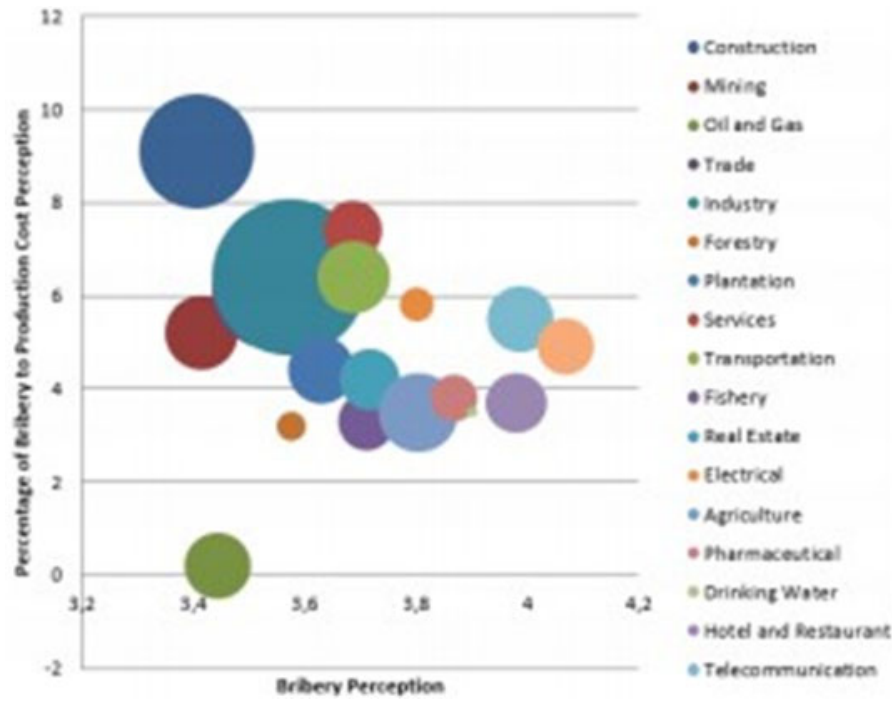

Figure 1. Indonesia's bribery perception, percentage of bribery to production cost, and Gross Domestic Product (GDP) perception according to business sector.

Figure 1 represents the aggregate bribery perception scores of the 11 sample cities according to their business sectors. Then, the results were mapped against the percentage of bribery to production cost. The size of each circle indicates the GDP generated by each business sector. Based on the mapping above, it is shown that the sectors most perceived as having higher levels of bribery are construction, oil and gas, mining, and trade. The construction sector has the highest percentage of bribery to production cost and has high bribery perception despite its major contribution to the GDP. This result is consistent with Stansbury's statement (2005) who found that construction is one of the sectors prone to corruption practices.

\subsection{Mapping of business sector bribery perception against the GDRP}

\subsubsection{Manado}

The construction sector was the largest contributor to the provincial GRDP of North Sulawesi, followed by the transportation sector in second place. Construction came first with the support from President Joko Widodo through his ambitious infrastructure development programs, especially outside Java Island. The data mapping shows that several sectors were perceived to have a higher potential for bribery. These sectors deal with natural resources, such as mining, oil and gas, and forestry.

\subsubsection{Bandung}

The business sectors perceived to have a higher potential for bribery in Bandung were related to natural resources: mining, forestry, and oil and gas. Bribery practice was also perceived to be 
prevalent in the construction sector. It was the second-largest contributor to the provincial GRDP of West Java after the trade sector.

\subsubsection{Banjarmasin}

The largest contributor to the provincial GRDP of South Kalimantan was the mining sector. In terms of topography, the island has a wealth of mining sites and forests. Despite the numerous mining sites in Banjarmasin and its status as the largest contributor to the provincial GRDP of South Kalimantan, the sector had a relatively low bribery perception. There were far more corruption cases in the forestry sector, especially illegal logging. It was exposed to the public and as a result, the sector became the top of mind of bribes in Banjarmasin.

\subsubsection{North Jakarta}

The largest contributor to the provincial GRDP of DKI Jakarta was the construction sector. Based on the results in other previous cities, construction was among the sectors with the highest bribery perception. For North Jakarta, however, bribery practice was perceived to be less ubiquitous thanks to the city's new administration led by Governor Basuki Tjahaja Purnama (Ahok), who had been determined to bring greater efficiency in governance, such as in business permit and licensing.

\subsubsection{Makassar}

The provincial GRDP of South Sulawesi most substantially came from the construction sector. On the other hand, the second-largest contributor was the trade sector, with the agricultural and service sectors in third and fourth places respectively. The plantation was perceived to be the most potential sector for bribery practice as Makassar has a great deal of plantation sector corruption cases.

\subsubsection{Medan}

The sector that was perceived to have the highest potential for and prevalence of bribery was mining, followed by agriculture and plantation in second and third places respectively. In terms of the provincial GRDP of North Sumatra, the greatest portion came from the sectors that deal with natural resources. Many corruption cases involving the city's plantation sector have been revealed to the public.

\subsubsection{Padang}

The survey found that the oil and gas, construction, plantation, and mining sectors were perceived to have a high potential for bribery. Other sectors that were perceived to have a high potential for bribery and among the top contributors to the provincial GRDP of West Sumatra include plantation and construction.

\subsubsection{Pekanbaru}

It was revealed that the sectors dealing with natural resource utilization were among the top contributors to the provincial GRDP. In terms of business sector bribery perception, the six sectors that had the highest score were those dealing with natural resources, such as forestry, agriculture, fishery, mining, plantation, and oil and gas.

\subsubsection{Pontianak}

The top provincial GRDP contributors were the construction, transportation, plantation, and service sectors. Meanwhile, in terms of bribery perception, transportation, telecommunication, and trade sectors had the highest potential for bribery practice.

\subsubsection{Semarang}

The provincial GRDP of Central Java largely derived from the trade sector. It was perfectly reasonable since Semarang - like Surabaya - is a port city. In addition to trade, the construction sector also contributed to the provincial GRDP of Central Java. In terms of bribery perception, the plantation sector was perceived to have the highest potential for bribery. 


\subsubsection{Surabaya}

The provincial GRDP of East Java mostly derived from the trade sector, while the second major contributor was the construction sector. Surabaya is also the largest city in Indonesia, which means a greater construction intensity takes place in the city. The next largest contributors to the provincial GRDP were the service and agricultural sectors. As expected, the oil and gas, mining, and forestry sectors were perceived to have a high potential for bribery. One of the reasons was the considerable time required for obtaining permits and licenses, which prodding the business people to resort to bribery to smooth out their businesses.

\section{CONCLUSION}

This study provides an overview of the bribery perception of the business sector and maps it against the provincial GRDP generated by each sector. According to the mapping, bribery perception greatly depended on the major business sectors a city has. The larger the sector was, the higher the bribery perception people had of the sector. Likewise, sectors that deal with natural resources, such as mining, oil and gas, and forestry, were also perceived to have a higher bribery potential across all sample cities. This finding is consistent with Stansbury (2005) and Martini (2012) who conclude that the construction sector and any sectors dealing with natural resources are prone to corruption. Meanwhile, in terms of the impact of corruption, the mapping result is rather inconclusive to determine whether the findings are more supportive of the "sand the wheels" or "grease the wheels" hypotheses.

\section{REFERENCES}

Dreher, A., \& Gassebner, M. (2007). Greasing the wheels of entrepreneurship? The impact of regulations and corruption on firm entry. Cesifo Working Paper No. 2013.

Fisman, R., Svensson, J. (2007). Are corruption and taxation really harmful to growth? Firm level evidence. Journal of Development Economics, 83 (2007), 63-75.

Huntington, S.P. (1968). Political order in changing societies. New Haven, CT: Yale University Press.

Kaufmann, D., Wei, S., 1998. Does grease money speed up the wheels of commerce? Mimeo, World Bank.

Leff, N. (1964). Economic development through bureaucratic corruption. The American Behavioural Scientist, $8(2), 8-14$.

Leys, C. (1965). What is the problem about corruption? Journal of Modern African Studies, 3, 215-230, Reprinted in A.J. Heidenheimer, M.Johnston, \& V.T. LeVine (Eds.) (1989), Political corruption: Ahandbook (pp. 51-66). Oxford: Transaction Books.

Lui, F. (1985). An equilibrium queuing model of bribery. Journal of Political Economy, 93(4), 760-781.

Mauro, P. (1995). Corruption and growth. Quarterly Journal of Economics, 110, 681-712.

Peter Kimuyu (2007), “Corruption, firm growth and export propensity in Kenya”, International Journal of Social Economics, Vol. 34 Iss 3 pp. 197-217.

Pham, H.T., Takayama, S. (2015). Revisiting the missing middle: Production and corruption. Working Paper Series from Centre for Efficiency and Productivity Analysis, School of Economics, University of Queensland, Australia.

Stansbury, N. (2005). Exposing the foundations of corruption in construction. In Corruption in Practice, Transparency International Global Corruption Report 2005. Transparency International.

Svensson, J. (2001). The cost of doing business: Ugandan firms experiences with corruption. In: Svenson, J. (2005). Eight questions about corruption. Journal of Economic Perspectives, 19 (3), 19-42.

Transparency International. (2011). Bribe Payers Index Report. 